\title{
BRICS: An Explanation in Critical Geography*
}

Krishnendra Meena**

\section{Introduction}

The BRICS group, though very much analysed since its conception, has not been able to attract sufficient attention from the discipline of geography. A large amount of literature has been dedicated to the economic effects of the creation of the BRICS (CHENG et al., 2005; FERCHEN, 2012; JEONG; KIM, 2010). Furthermore, the literature in International Relations does reflect on regions as security constructions (BUZAN; WAEVER, 2003; LEMKE, 2003), but the definitions of 'region' itself are not clear in both formulations, and the

\footnotetext{
* Article submitted on September 25th, 2013 and approved for publication in November 4th, 2013.

** Krishnendra Meena is an assistant professor at the Centre for International Politics, Organization and Disarmament (CIPOD), School of International Studies, Jawaharlal Nehru University, New Delhi since 2004. He has been teaching M.A. and M. Phil courses on Political Geography, Advanced Political Geography and Geographical Information Systems and has designed a course on Concepts and Issues in Geopolitics for M. Phil students at CIPOD. E-mail: meena.krishnendra@gmail.com.
}

CONTEXTO INTERNACIONAL Rio de Janeiro, vol. 35, n² 2, julho/dezembro 2013, p. 565-593. 
spatial aspect about regionalization is not specified. Literature on regionalism and its newer version, arrived at through the globalization processes, does lean towards the recent and novel understandings of 'region' at the international level where 'the formation of regions takes place at the interface between global economic and technological forces and national realities' (VAYRYNEN, 2003). On the other hand literature in critical geography also only alludes to the phenomenon of the BRICS, but does not sufficiently spatialize the BRICS (NEUMANN, 2010; SIDAWAY, 2012). This paper seeks to address this prominent gap in the literature on BRICS, as the globalization processes create spatial patterns in the world system which up to now have not been experienced and therefore have not been analyzed.

A unique characteristic of the BRICS group is its geographical spread as evident from the location of these five constituent states which are situated in four continents. Such spatially variegated groupings like the BRICS can be analysed and interpreted in Critical Geography and Critical Geopolitics literature through three important concepts: a) Space b) Geographical and Geopolitical Imaginations and c) Region. This paper seeks to explain BRICS through these conceptual tools. Such exercises help us to recognize and understand the new spatialities which occur at the international level due to the recent phase of globalization.

Critical Geographers have conceptualized space in multiple formulations e.g. Harvey (1973; 2005) (Absolute, Relative and Relational) and Lefebvre (experienced space, perceived space and lived space). In the context of the BRICS, these formulations of space are relevant if the grouping is considered to be a visualization of the global space. A primary perspective to examine the BRICS is through Harvey's Geographical Imaginations which he argues "enables the individual to recognize the role of space and place in his own biography, to relate to the spaces he sees around him, and to recognize how transacti- 
BRICS: An Explanation in Critical Geography

ons between individuals and between organizations are affected by the space that separates them" (HARVEY, 2005).

An extension of the geographical imaginations is inferred in John Agnew's geopolitical imaginations, a term which he utilizes to critically evaluate the classical geopolitical theories such as Mackinder's Heartland and Spykman's Rimland. He argued that a) traditional geopolitics involved seeing the world-as-a-picture, as an ordered, structured whole, separating the self who is viewing from the world itself; and b) the world pictured beyond the horizon is a source of chaos and danger. This paper seeks to analyze whether the BRICS are such a visualization of global space and if the BRICS are also a geographical strategy in the classical sense.

Similarly, the suggestion that regions are strategic constructions (ALBERT; REUBER, 2007) and manifestations of social production of space (NEUMANN, 2010) will be tested through the case of BRICS in this paper. This paper will examine this through the assumption that globalization is the major social and economic development of the $21^{\text {st }}$ century.

The study, accordingly, is divided into four sections, in which the introductory section deals with the formation and evolution of the BRICS as a grouping. The subsequent sections engage with a) conceptualization of 'space' in geography and BRICS b) geographical and geopolitical imaginations and BRICS and c) concept of 'region' in geography and international politics with reference to BRICS as a grouping.

\section{Conceptions of 'Space' and the BRICs}

Space is, in many ways, the key topic of geography. It is probably the most often cited term that gives geography its identity and unifying 
focus (ELDEN, 2009, p. 262). Due to its diverse usage and multiple implications in natural and social sciences, it has been one of the most difficult concepts to define. In geography, both human and physical geographers use the word regularly, but it is frustrating to define and, in the minds of many, appears so diverse as to lack any useful specificity (ELDEN, 2009, p. 262). It is also very interesting to note that the term has been extensively debated in the realm of philosophy. Geographers have been late to adopt the term because of the emphasis in geography on 'geo' rather than on space. Recent attempts to understand space in geography delve into answering the following key philosophical questions:

a) Do we experience in space or experience space?

b) What is the distinction between space and place?

c) What is the relation between space and time?

d) Is the world in space or is space in the world? (ELDEN, 2009, p. 262).

These questions inform most of the thinking about space, but no concrete definition/definitions have been constructed and none can be visualized for the immediate future. In general, the significant strands of thinking about space are in broad agreement about the ways in which space is understood by various disciplines. In geography, space has been thought of in a trilogy of absolute, relative and relational space. Subsequent explanations interpret, explain and qualify these three categories and develop upon this trilogy. It is relevant at this stage to explain these formulations of space as they form the background for this paper which intends to situate the BRICS as one such variety of spatial conceptions. Space as an absolute is understood as a geometrical system of organization (usually Euclidean geometry with $\mathrm{x}, \mathrm{y}$, and $\mathrm{z}$ dimensions) in which people and objects are located and move through. Here, space is understood as natural, given, essential, and measurable (KITCHIN, 2009, p. 268). This is space as fixed, as a container, as something in which all things happen. Space 
can therefore be represented as a two or three dimensional grid, imposed over a landscape in surveying or cartography (ELDEN, 2009, p. 264). For our purposes, the BRICS countries individually constitute absolute space on the earth's surface. John Agnew's (1994) 'territorial trap' seeks to clarify such absolute conceptions of space in the International Relations theory. He labels them as the geographical assumptions of IR theory and argues that the following assumptions have led to a territorial conception of the state in the first place.

a) State territories have been reified as set or fixed units of sovereign space. This has served to de-historicize and de-contextualize processes of state formation and disintegration.

b) The use of domestic/foreign and national/international polarities has served to obscure the interaction between the processes interacting at different scales.

c) The territorial state has been viewed as existing prior to and as a container of society. As a consequence, society becomes a national phenomenon (AGNEW, 1994, p. 59).

The state centricity of the transactions carried out in the international system reinforces the state's territorial character and its territoriality is based on an absolute conception of space. The latter two assumptions emanate from the first one and emphasize the absolute nature of the state-space. State spaces are represented as absolute spaces and containers of societies which inhabit them. This holds true for the individual components of the BRICS, as the constituent states act in the international system as other similar territorial entities. For the BRICS as a group, an absolute conception is a misnomer, as the group itself evolved in relation to the developed world. Nevertheless, the BRICS states, owing to the prevalence of the Westphalian territoriality in the international system, do assert administrative control over their respective territories.

The three Eurasian/ Asian members in the BRICS, Russia, India and China, in fact grapple with serious territorial disputes with their res- 
pective neighbours. To briefly list the territorial disputes for China would include most of its neighbours including another BRICS state, India. China has territorial land disputes with Bhutan, Vietnam and Myanmar. The maritime territorial disputes involve The Phillipines and Taiwan (Scarborough Reef, South China Sea); and Malaysia, The Phillipines, Taiwan, Vietnam and Brunei over the Spratly Islands in the South China Sea. In the same region, Vietnam and Taiwan claim the Paracel Islands. Most recently, China's relations with Japan have taken a downturn because of the territorial claims China has made on Senkaku-shoto/ Diaoyu- Tai, over which the Japanese have effective territorial control. With India, China has since 2005 entered into a dialogue over various issues of territorial control and boundary management which extend across the Himalayan expanse (CIA, 2013). India, apart from the boundary disputes with China, faces problems with Pakistan on its western expanse; many of these boundary questions have their roots in the partition of the country into two separate states during independence in 1947. Illegal Bangladeshi immigration has been a constant source of discussion in the Indian media. This migration occurs because of lack of proper demarcation of the border and the existence of enclaves on both sides of the border. Effective management of the border with Bangladesh is also lacking. There are contested boundary sections with Nepal over which a Joint Border Committee frequently deliberates, especially with respect to the demarcation of river boundaries and the sharing of water of the many rivers which straddle Indian and Nepalese territory. Russia, owing to its vast expanse and sharing of borders with many states in Europe and Asia, also shares many cartographic anxieties. The sovereignty dispute over the islands of Etorofu, Kunashiri, Shikotan, and the Habomai group, known in Japan as the "Northern Territories" and in Russia as the "Southern Kurils," occupied by the Soviet Union in 1945, now administered by Russia, and claimed by Japan, remains the primary sticking point to signing a peace treaty formally ending World War II hostilities. China and Russia have de- 
marcated the once disputed islands at the Amur and Ussuri confluence and in the Argun River in accordance with a 2004 Agreement, ending their centuries-long border disputes (CIA, 2013).

The southern hemisphere countries in the BRICS also face problems related to boundary disputes. In particular, Brazil has a dispute with its neighbours, Argentina and Uruguay, over the Braziliera/Brasiliera Island in the Quarai/Cuareim River, which leaves the tripoint with Argentina in question. South Africa faces major management problems on its borders with Zimbabwe, Lesotho and Mozambique (CIA, 2013).

"In opposition to the absolute view of space, yet sharing many of its essential elements, is 'relative' space. One way to understand this is to recognize that space is not an empty container, but filled with objects and relations. Space is, according to this argument, in part dependent on that relation to objects, as it is a positional quality of a world of material things. Relative space can also be based on challenging the fixed geometries of absolute space. This would include the development of multiple geometries that rejects some of the key postulates of Euclid, while retaining a coherency and consistency, and recognizing that the perspective of the observer plays a key role" (ELDEN, 2009, p. 264). This way of thinking about space coheres with the way the BRICS have been formulated in geopolitical competition with the 'West'. The term global South in opposition to the global North is another example where the term 'North' represents the developed economies and the term 'South' represents the developing world. So, it is very difficult to define the North as well as the South, if it is not spoken of together or in relation to each other, as indicated by Raewyn Connell (2009):

The geographer's "South" is not exactly the same as the "South" in UN trade debates, or the "third world," or the "less developed countries," or the economists" "periphery," or the cul- 
tural theorists' "post-colonial" world, or the biologists" "southern world," or the geologists' former Gondwana-though there is some overlapping along this spectrum. I mainly talk of "metropole" and "periphery," but there is enormous social diversity within each; recognizing the polarity is only the beginning of analysis, not the end.

Thus, there is a South, only because there is a North. BRICS in its evolution has followed similar trajectories and has transformed from a developing space of the South into a space of emerging economies in relation to a space of developed economies of the North.

A development over the absolute and relative conceptions of the space is relational space. In this sense, space is relational because objects exist only as a system of relationships to other objects. Space is thus seen as the product of interrelations, as constituted by them. Space is a multiplicity, heterogeneous rather than homogenous, plural rather than singular. Space is, therefore, always in the process of making, never finished or closed (ELDEN, 2009, p. 265). Space, it was argued, was not a given, neutral, and passive geometry, and essentialist and teleological in nature. Instead, space was conceived as relational, contingent, and active, as something that is produced or constructed by people through social relations and practices. Space is not an absolute geometric container in which social and economic life takes place, rather it is constitutive of such relations (KITCHIN, 2009, p. 270). Such conceptions of space emanate from the work of the French Marxist philosopher, Henri Lefebvre, particularly his book The Production of Space (1974) which was translated in 1991 into English (LEFEBVRE, 1991). Such a conception of space has ramifications for BRICS. The fundamental reason behind the creation of BRICS seems to provide an alternative to the economic and financial institutions (IMF and World Bank) as the primary regulators of the international economic system. The BRICS development fund and 
the BRICS bank are efforts in this direction; to capture some of the economic space as donors and aid providers with less stringent conditionalities to the developing world. The two institutions also aim to counter the "unintended negative spillovers of unconventional monetary policies of certain developed economies" (VENU, 2013). In many ways the BRICS, therefore, are an attempt to alter the economic relations within the global space and it a strategy in relation to that of the 'West'. BRICS as a group can then transform the global space, not in its absolute sense, but in very fundamental ways by transforming the global relations of the North and the South. Emergence of China as an economic powerhouse and the subsequent geopolitical shifts indicate, there are multiple ways to think about the global space. A pertinent example is the gradual influence and acceptance of Chinese capital on the African continent. The project of the United States of America to re-formulate its Asia-Pacific strategy into Indo-Pacific is another example of how space is relational and how it is produced in consonance with time. The term Indo-Pacific, in this instance, is a geopolitical code for China, a new and geo-strategic conception of the space connecting the two oceans (Indo-Pacific) which encircle China geographically.

After the acceptance of the idea that space is constantly produced by society and is dynamic in nature viz. Harvey (1973) and Lefebvre (1991), geographers have invested intellectually in the project of human practices while conceptualizing space. Reflecting upon own earlier work Harvey (2005, p. 214) asserts

I still hold to a fundamentally correct position with respect to the social construction of space: space is neither absolute, relative nor relational in itself, but it can become one or all simultaneously depending on the circumstances. The problem of the proper conceptualization of space is resolved through human practice with respect to it. In other words, there are no philosophical 
answers to philosophical questions that arise over the nature of space-the answers lie in human practice. The question "what is space?" is therefore replaced by the question "how is it that different human practices create and make use of distinctive conceptualizations of space?"

The most influential description and account of space in the twentieth century is considered to be that of Henri Lefebvre. A self-proclaimed Marxist, Henri Lefebvre, proposed a dialectical way of thinking about space in The Production of Space (ELDEN, 2009, p. 265). The academic project coined by him is spatiology, and it involves, among other things, a rapprochement between physical space (nature), mental space (formal abstractions about space), and social space (the space of human action and conflict and 'sensory phenomena') (MERRIFIELD, 2003, p. 170).

\section{Lefebvre's Social Production of Space}

Lefebvre's conception of space has been interpreted since the publication of his book and has received wide attention in the Anglophone world after its translation in 1991. Like Marx, his objective was to analyse the capitalist society but the object of his research was the nature of social space in the capitalist society. Lefebvre correspondingly tries to demystify capitalist social space by tracing out its inner dynamics and generative moments in all their various guises and obfuscations (MERRIFIELD, 2003, p. 171). Here, generative means 'active' and 'creative', and creation, and, says Lefebvre (1991, p, 34), 'is, in fact, a process'. Thus getting at this generative aspect of space necessitates exploring how space gets actively produced (MERRIFIELD, 2003, p. 171).

For Lefebvre, there are three key determinants of space: spatial practices, representations of space and spaces of representation (or repre- 
sentational space) (KITCHIN, 2009, p. 270). Spatial practices refer to the processes, flows, movements, and behaviours of people and things that can be perceived in the world (KITCHIN, 2009, p. 270). Spatial practices can be revealed by 'deciphering' space and have close affinities, to people's perceptions of the world, of their world, particularly with respect to their everyday world and its space (Merrifield, 2003, p. 174). Can the BRICS then be thought of as a product of one of the most significant spatial process of the last three decades, i.e. globalization? As an economic process, globalization has created a global interdependence among states for commodities, has created flow networks with tremendous spatial dimensions, has improved mobility of the humans and has subsequently altered the notions of space. "There is a spatial dialectic to globalization. On the one hand, some places have moved closer together in relative space. The trajectories of national, regional and local economies have become even more enmeshed within a network of global financial flows and transactions" (SHORT, 2001, p. 9). One can argue that it was possible to conceive of the BRICS together by the consultant Jim O'Neill, and later on as a BRICS space or group of states because these states ended up deriving economic benefits from global capitalism during the same phase and economic gains translated into assertiveness in the political realm.

The process has created similar spaces within respective states, created large middle classes which derived economic benefits and at some levels a cultural uniformity can also be witnessed. An additional effect of the process is that it provided the BRICS with common objectives vis-à-vis the developed West and, as stated above, these states began to challenge various issues at international forums.

Representations of space, refers to conceptualized space, to the space constructed by assorted professionals and technocrats. The list might include planners, engineers, developers, architects, urbanists, geographers, and others of a scientific inclination (MERRIFIELD, 
2003, p. 174). Representations of space refer to the discursive media (e.g., images, books, films, maps, plans, and so on) which serve to represent the world spatially in order to make sense of it and to think through what is and might be possible (KITCHIN, 2009, p. 270). This space comprises the various arcane signs, jargon, codifications and objectified representations used and produced by these agents and players. Lefebvre says that it's always a space which is conceived, and invariably ideology, power and knowledge are embedded in this representation (MERRIFIELD, 2003, p. 174).

For the BRICS, such codifications, jargon and symbols have been plentiful (emerging economies, regional powers, anchor countries, emerging powers, middle powers etc.), and the possibilities for the BRICS and the global space as a whole have been subsequently marked and identified. These labels are reflective of the prior metaphors about the developing world like the Third World, Less Industrialized countries and the Global South. Sidaway (2012, p. 50) traces geopolitics in categories like the BRICS and argues it will need a novel and nuanced mapping of the world to denote the gradual dissolution and decomposition of the Third World into new geographies of development. The BRICS are a manifestation of the contemporaneous changes in the geographies of development. A new global spatiality is the experience of the last few decades in which the BRICS nations are more present than ever in modern human history dominated by Europe or the United States.

Representational space or space of representations is directly lived in space, the space of everyday experience. It is space experienced through complex symbols and images of its 'inhabitants' and 'users,' and 'overlays physical space, making symbolic use of its objects' (MERRIFIELD, 2003, p. 174). Spaces of representation are the spaces that are produced by people in everyday practice; the spaces lived in and felt by people as they weave their way through everyday life (KITCHIN, 2009, p. 270). The overriding feature of the new global 
experience is the rise of China based on its manufacturing sector. The influx of Chinese manufactured goods is pervasive in its reach. Economic growth in China has been due to the government's ability to promote the manufacturing industry in the export sector (JEONG; KIM, 2010, p. 10). Russia and Brazil have reinforced their presence in the economic sector by providing raw materials to the international market. Russians are the main suppliers of natural gas and petroleum to the European market, whereas Brazil contributes extensively by supplying raw materials for heavy industry. India, on the other hand, has been the main beneficiary of the global interdependence in the services sector and has stood out in terms of providing a skilled workforce in the international market. Thus, the BRICS are making their presence felt in the international system by both contributing to it and also deriving benefits from it due to the globalization process. A BRICS experience can be identified and is increasingly more visible in the international arena. The BRICS as group have come to recognize this particular aspect and the consequence is the assertion of the BRICS space by gradual evolution of the BRICS group and its related institutions. Geopolitically, the BRICS have provided the developing world with a sense of belief vis-a-vis the West, that it is possible to achieve growth and development by subscribing to the idea of globalization.

\section{Geographical/Geopolitical Imaginations and the BRICS}

Harvey explains the presence of geographical imagination as pervasive in human life and asserts that:

This "spatial consciousness" or "geographical imagination" was manifest in many disciplines. Architects, artists, designers, city planners, anthropologists, historians, sociologists, political scientists, psychologists, ecologists and economists as well as geographers and phi- 
losophers have all appealed to it $[\ldots]$. (HARVEY, 2005, p. 212).

Further, he calls for a combination of the geographical imagination with a sociological imagination to understand reality better. "The relations between social processes and spatial forms needed to be better understood as a prerequisite to well-grounded critical research on urbanization, modernization, diffusion, migration, international capital flows, regional development, uneven geographical development, geopolitics, and a host of other subjects of considerable importance" (HARVEY, 2005, p. 212).

Though Harvey's imaginations refer to the individual, such geographical imaginations can be constructed at the level of nations, as evident from the work of Benedict Anderson titled Imagined Communities (1983). Furthermore, it is possible to imagine such communities at the international level as a globalized world and an intense flow of information, commodities, ideas and people facilitates such imagination. The BRICS are also one such geographical imagination where the constituent states have been able to identify/recognize the relationship among them and they have been able to forge a group based on certain common characteristics and features. This recognition of commonalities, in turn, creates the common ground for the members to forge a group and helps to distinguish it from similar entities, in this case, the West. Such arguments can at least be substantiated theoretically, "each form of social activity defines its own space" (HARVEY, 2005, p. 214).

Harvey further presses the issue about globalization's impact upon various imaginations of space, "Globalization (however it is construed) has forced all sorts of adjustments into how the sociological imagination (if such a coherent concept is still viable) can now work. It cannot, for example, afford to ignore the basics of political-economy nor can it proceed as if issues of national and local differences, space relations, geography and environment are of no consequence" 
(HARVEY, 2005, p. 215).Thus globalization has shaped the spatiality owing to its pervasive nature and such spatiality is also reflected in the way the BRICS have been formulated as a geopolitical group. Such arguments have resonance with the 'geopolitical imagination' explained by John Agnew while explicating theories of traditional geopolitics.

Critiquing the geopolitical theorizing by the likes of Halford Mackinder, Mahan, Haushofer and Spykman, Agnew labels such attempts as geopolitical imagination and visualization and suggests they are a defining feature of modernity which is exemplified by two elements: 1) that the world is seen as a picture, as an ordered structured whole, separated from the self who is viewing from the world, and 2) the world pictured beyond the horizon is a source of chaos and danger (AGNEW, 1998). If the geographical spread of the BRICS constituent countries is an indication, the BRICS are a geopolitical construct in the traditional geopolitics mold. A careful inquiry of the BRICS summit declarations attests to this notion, as the statements at the end of each of the five BRICS summits held so far have displayed a gradual evolution toward inclusion of security as a vital concern of the BRICS. The First Summit at Yekaterinburg in 2009 listed as its main concerns the global financial crisis, global environmental problems, reform of global financial institutions, energy security, terrorism and protection of human rights (President of Russia, Official Web Portal). Fast forward to the Fifth BRICS Summit in Durban (BRICS, 2013b) and the eThekwini declaration (BRICS, 2013a) has strong and clear geopolitical undertones. Beginning with a call for global peace and security in statement 1 to statements $21,22,24$, and statements 26 to 33 , the intention is to address issues ranging from the UN's role in ensuring international peace and security, the role of the UN peacekeeping forces in Africa, the security situation in Syria, Palestine, the Iranian nuclear issue, Afghanistan, Mali, DRC, to international terrorism (BRICS, 2013a). 
The geographical location of the BRICS countries makes it safe to assume that BRICS have a global reach. It also comfortably dovetails with the traditional geopolitical theories of 'heartland' (MACKINDER, 1943) and 'rimland' (SPYKMAN, 1942). A brief exposition will clarify and make evident the suspicion that BRICS could be a geopolitical imagination which has the potential to be practised as a global geostrategic design. The concepts of heartland and rimland, it is alleged, formed a geostrategic background for the containment policy of the United States during the Cold War (GERACE, 1991, p. 347). BRICS constituent countries span four continents. Russia is present in both Europe and Asia and increasingly there is a movement that supports the idea of Eurasianism/ Neo-Eurasianism after the leading geopolitical thinker Alexander Dugin (SHEKHOVTSOV, 2009, p. 697). The heartland is purely Eurasian in its geographical expanse (MACKINDER, 1943, p. 597). China comprises the rimland, the concept entailing the coastal states of the larger Eurasian continental landmass spanning from the Western European coast to the Kamchatka Peninsula in North eastern Russia (SPYKMAN, 1942). The third Asian component of the BRICS is India, which also forms a part of the rimland. This troika of Russia, China and India geographically dominate the largest continental landmass on earth, due to their respective size ranking $1^{\text {st }}, 4^{\text {th }}$ and $7^{\text {th }}$ in terms of their areal expanse in square kilometres (CIA, 2013). Furthermore, these three countries undoubtedly have the military capabilities to dominate the entire Eurasian landmass. Russian military capabilities are still formidable after the collapse of the Soviet Union, whereas India and China are recorded in 2012 as the biggest buyers of defence and military equipment with India accounting for $12 \%$ of the global imports in arms and China procuring $6 \%$ of the global imports (SINHA, 2013) adding to their already established military capabilities.

South Africa utilizes its pre-eminent status on the African continent to mediate and facilitate the investment for resource extraction and 
development. This was evident in the $5^{\text {th }}$ BRICS Summit in March 2013, when many African governments were invited to interact with the representatives of the BRICS countries. South Africa projects itself as a gateway to Africa. The summit itself was christened as "BRICS and Africa: Partnership for Development, Integration and Industrialization" to attract investments in the fields of development and industrialization in Africa and subsequently many schemes for investment in Africa were announced during the summit (BRICS, 2013a). South Africa tops the list of arms buyers on the African continent and exerts considerable influence in the affairs of the continent as does Brazil. These two states are in no sense marginal to global geopolitics and have played an important role in debates surrounding the status of the global environment and have been influential in multilateral diplomacy on these issues.

Brazil and South Africa, the southern hemisphere components of BRICS, form parts of the Outer or Marginal Crescent in the geopolitical schema of Mackinder, whereas they form parts of the "Three Islands" in the terminology of Spykman (1942). In both the geopolitical schemes these two BRICS countries are accorded a marginal status. Brazil ranks fifth in terms of the areal expanse of a state and South Africa ranks $25^{\text {th }}$ in terms of its area in square kilometres. An important feature of both these states is that they also dominate their respective continents in terms of their military capabilities and influence and could safely be considered as the most powerful states in their respective regions.

\section{Brazil and South America}

Among the Latin American countries, Brazil stands out for its skilful diplomatic performance, which has translated into territorial gains from all of its neighbours throughout the first decades of the twentieth century, thus fulfilling the basic geopolitical law of expansion into the continental heartland (westwards) (KACOWICZ, 2000, p. 
85). Latin American geopolitical tradition is closely aligned with military geostrategy (BARTON, 2003, p. 62) and has borrowed heavily from the geopolitical thought in Europe which emanated in the late $19^{\text {th }}$ and early $20^{\text {th }}$ century. The best example in support of this statement is the predominance throughout the continent of military geography institutes. Militarism and cartography, principally used for political propaganda purposes, are the footings of the political geography foundations that exist (DODDS, 1993, p. 362) in South America. The geopolitics of the three major states (Argentina, Brazil and Chile) are deeply related to each other, Brazil being the dominant state in the affairs of the continent. While Brazil is the dominant player in the Southern Cone, the second tier states of Argentina and Chile have projected their contrasting viewpoints regarding the sharing of resources as well as demarcation of boundary lines. Brazil ranks tenth in the list of countries with highest defence budgets in absolute value at US \$ 35.5 billion in 2012 and it is an increase of $73 \%$ over 2006 (FERREIRA, 2013). With its expansive territory, Brazil occupies most of the eastern part of the South American continent and its geographic heartland, as well as various islands in the Atlantic Ocean. Geopolitical thought in Brazil has witnessed a systematic development since the days of Mario Travassos who in the 1930s argued that Brazil must develop (both internally and internationally) on East-West axis ("longitudinal Brazil") instead of merely along the Atlantic coastline (CHILD, 1979, p. 90). During the 1970s, the leading figure in Brazilian geopolitical thought General Golbery de Couto e Silva (CHILD, 1979, p. 90; KACOWICZ, 2000, p. 87) argued that Brazil must progress in an orderly manner from control of her own national territories to continental projection to international influence by means of the following principles: national integration and effective use of space; interior expansion and pacific external projection; containment along the frontier; participation in the defence of Western Civilization; continental collaboration; and collaboration with the developing world (SCHWAM-BAIRD, 1997, p. 4). 
Since the 1970s, the Brazilian state-owned petroleum company, Petrobras, has discovered offshore oil deposits in the offshore region of Rio de la Plata. The area under offshore oil exploration is approximately 1 million $\mathrm{km}^{2}$. This discovery has changed the Brazilian oil production and consumption in its favour and it achieved certain level of self sufficiency by the year 2006 (BOFF; SANTANIELLO, 2006, p. 63-64).The offshore oil basins are located in Rio de la Plata basin of the Southwest Atlantic Ocean. In terms of the utilization of the oil resources from the South Atlantic, Brazil has embarked upon a Blue Amazon strategy to indicate the utilization of oceanic resources for power projection on to the global sphere.

On the South American continent Brazil has played the role of regional power, and though its dominance has been challenged by neighbouring Argentina, because of its large size and larger economy, Brazil's standing in regional affairs has been undisputed (MEYER, 2011, p. 1). Brazil's primary circle of international relations is with its Latin American neighbours. In the region, Brazil has been a founder member of the Organization of American States (OAS) during the formation of the organization under the aegis of the United States in 1948. Another regional group within the region is the Mercado Comun del Sur (Mercosur) or the Southern Common Market, which was formed in the year 1991 and which intends to develop a European Union type of community for trade and investment in the region. Later in 2008, Mercosur was merged with the Andean Community of Nations (CAN) and the Unión de Naciones Suramericanas (UNASUR) was created as a customs union for South America. Brazil's desire to have larger say in the affairs of the world is manifest in its intense lobbying for a permanent seat in the Security Council of the UN, which is examining the possibility of a reformed and expanded Security Council (WOUTERS; RUYS, 2005, p. 20), which would be more representative of the current power structure of the world. A recent feature of the Brazilian geopolitics is the grouping 
with the countries of similar levels of development which are negotiating with the traditional economic powers of the world. These negotiations relate to the question of trade in the World Trade Organization, which is biased towards the West. The Environmental Regime under the United Nations in the UN Conference of Environment and its related bodies involves the Environment Versus Development debate. Brazil in this context has developed a partnership with India, South Africa and China, under various groupings like the India, Brazil and South Africa (IBSA) group and the Brazil, India, Russia, China and South Africa (BRICS) group. These groups are a manifestation of the Brazilian ambition to have global influence.

Thus, apart from wielding influence in their respective regions, the BRICS states also intend in the future to form a formidable security alliance which has implications for global geopolitics. Their presence in four continents provides them with considerable leverage in global geostrategic calculations and the BRICS willingness to become engaged in issues of international security indicates gradual transformation of security architecture itself at the global level. Though, initially coined as a metaphor for rising economies, the BRICS have now assumed a geopolitical role which has the potential to be translated into a geographical strategy or a geopolitical imagination in traditional geopolitics terminology. This invites scrutiny from a critical geopolitical perspective on various counts including 1) the fact BRICS is a geographical strategy formulated by state apparatuses of the constituent states, 2) the geographical strategy at the global level revisits the 'containment' policy of the United States of America during the Cold War, 3) the BRICS owing to their economic growth in the recent decades seem to have assumed the role of the new elite of the world and have embarked on a project which befits the 'traditional' elite of the world i.e. the West, creating financial institutions in the same pattern as the IMF and the World Bank, 4) a sense of imitation of the West can be inferred through the creation of the 
BRICS itself, as the BRICS states, based on the established notions of growth and development, imagine themselves to be at the same level and hence the group. Moreover, the recently announced framework for the BRICS Development Fund and BRICS Bank indicates a similar model as adopted by the IMF and the World Bank with contributors donating according to their economic strengths rather than based on an equal partnership (VENU, 2013).

There are certain similarities about the BRICS states which allow them to be imagined together and give some semblance to the BRICS as a region. The following section examines the concept of region and its applicability to the group, BRICS.

\section{Concept of Region and BRICS}

The etymology of the term 'region' in English stretches back to $14^{\text {th }}$ century when it evolved from the Latin word regio meaning direction, boundary, or district, linked to regere, meaning to direct or rule (TOMANEY, 2009, p. 136). Geography, as a discipline has witnessed a sustained focus on the study of regions but a recurring and constant theme is that regions exhibit homogeneity in terms of various characteristics, and that defines them as regions.

Regions in geography are also marked by a peculiar distinction of 'formal' and 'functional' regions. Formal or uniform regions are areas defined by one or more of the features that occur within them (TOMANEY, 2009, p. 140). The functional or nodal region is a geographically delimited spatial system defined by the linkages binding particular phenomena in that area. Which phenomena? It depends on what kind of system we are interesting in knowing about (TOMANEY, 2009, p. 140). Relevant examples of functional regions are economic, cultural, political, ecological etc (VAYRYNEN, 2003, p. 26). A major defining feature of the study of regions in tradi- 
tional geography has been to study the uniqueness and character of a region with all the internal causal connections which make it special and differentiated from others. Therefore, it acquired a descriptive character. David Harvey summarizes it succinctly while looking at the conceptions of region, "The "region" is possibly the most entrenched of all geographical concepts. Within the discipline it has proven the least flexible, mainly because of its central role in those essentialist definitions of the subject which rest exclusively on the study of chorology or regional differentiation" (HARVEY, 2005, p. 245). In general, the region is defined in terms of its homogenous qualities or geographical contiguity and sometimes in terms of its coherent relations between diverse elements. In looking for similarities among the BRICS countries, two important aspects can be highlighted, 1) as outlined above, BRICS states are regional powers in their respective regions and 2) BRICS states individually are products of the recent phase of globalization and its allied processes.

Recent attempts to conceptualize region have stressed the value of establishing its connections with space and place. For instance Allen et al. (2002) lay down two principles to define/conceptualize region; first, it embodies a strongly relational approach to thinking about space and place. That is, it understands both space and place as constituted out of spatialized social relations-and narratives about them-which not only lay down ever-new regional geographies, but also work to reshape social and cultural identities and how they are represented. Second, it acknowledges that such studies are always done for a purpose, with a specific aim in view. Whether theoretical, political, cultural or whatever, there is always a specific focus (ALLEN et al., 2002, p. 2). Both the aforementioned principles of conceptualizing space are applicable to the BRICS as a group. For the BRICS countries, the relevant socio-spatial categories prior to the recent phase of globalization were the 'Third World', developing economies and the global South or that is how they were represented. 
The initial narrative was that they were striving for the levels of development already achieved by the west and following similar linear models of growth and development.

But in many instances these categories were the 'other' of the global North, the West and the First World. Hence, they were relational categories (SIDAWAY, 2012, p. 49-50). The current narrative about the BRICS' economies reflects the concerns of globalization and calls them as 'rising', 'emerging' or 'anchor countries' and denotes a new spatiality. Sidaway (2012) argues in the same article that such categories are not innocent and have many motives behind them. In the case of the BRICS, the motives are clear from the fact that the term BRIC was conceptualized by a business consultancy firm. Thus, there is a purpose behind such regionalization schemes. Furthermore, as Neumann argues, taking cue from analysis through discursive formation of the region, that "practices and discourses construct regions through institutionalized processes and reflect asymmetrical power relations" (NEUMANN, 2010, p. 369). The strengthening of regional imaginations and levels of political authority beyond the nation-state also demonstrates the way in which the spatial organisation of politics - in the sense of spatial constructions, representations and imagined communities - is not only an inherent element of ongoing political change, it rather also seems to be one of its most challenging structuring principles (ALBERT; REUBER, 2007, p. 550).

The BRICS as a region will be rather difficult to analyze and justify through the traditional conceptions of region which put a premium on geographical contiguity, homogeneity and place the 'region' on a scale below the state. The political ecology approach with its leanings towards the social production of spaces and places and the mandate to analyze the spatiality of social relations, does provide for such regional formations. As regions are discursive formations, power relations are embedded in them which favor certain formation over others. 


\section{Conclusion}

The BRICS group defies many aspects of conventional logic with respect to international organization and global governance. The most visible is the geographical location of the BRICS constituent states, as Brazil, Russia, India, China and South Africa are situated on four continents, which raises important questions about conceptions of global space. Literature on the concept of space, which sometimes delves into philosophy, allows for such variegated geographies to be bound by certain common criteria. Influential in this strand of thinking about space is the Lefevbrian notion of space and its tri-fold typology, spatial practices, spaces of representation and representations of space. Combined together they put value on the social production of space. The BRICS have been such a social production of space owing to the dominant social activity of globalization. Globalization with its heightened flows of information, commodities, people and ideas also allows for geographical and geopolitical imaginations. The interactions occurring due to globalization facilitate the imagination of spaces internationally, which is not possible otherwise. These imaginations assume a geopolitical character by the simple fact that the constituents are nation-states which are geographical and geopolitical players. Cohesion of the BRICS depends upon a common geopolitical agenda. Once the alliance has evolved, the process of 'othering' takes place vis- $a$-vis the West. Increasing reference to issues of security in the BRICS declarations is an example. Apart from 'hard' geopolitical issues, the group has rallied together on many issues of international importance eg. global environmental problems and the Doha trade negotiations. Region, the last concept employed to understand BRICS, generally, in geographical literature is utilized to understand regions within the state. On the other hand, the term is frequently used to understand regions internationally, in the form of economic organizations or geographically contiguous free- trade zones. The BRICS, although not contiguous, assume a re- 
gional character because of the metaphors employed to explain the developing economies which are common to the BRICS states, like the emerging economies, developing countries, rising powers etc. One more common factor may be the realization that their emergent status is a consequence of the acceptance of global capitalism.

This paper demonstrates that there is a need to spatialize the BRICS and such an explanation can be validated through critical geography. The conceptual tools employed place the phenomenon of BRICS in the incumbent phase of globalization, where states accrue similar trajectories of economic growth. This in turn leads to a common agenda in the international arena and generates the need for the group to be cohesive. An added observation is that BRICS constituent countries have partially been able to overcome the limitations posed by their location in respective regions, thus acquiring a profile which is extra-regional, and hence the need to spatialize the BRICS.

\section{References}

AGNEW, John. The Territorial Trap: The Geographical Assumptions of International Relations Theory. Review of International Political Economy, v. 1, n. 1 , p. 53-79, 1994.

. Geopolitics: Re-visioning World Politics. London: Routledge, 1998.

ALBERT, Mathias; REUBER, Paul. Introduction: The Production of Regions in the Merging Global Order-Perspectives on "Strategic Regionalization". Geopolitics, v. 12, n. 4, p. 549-554, 2007.

ALLEN, John; MASSEY, Doreen; COCHRANE, Allan. Rethinking the Region. London: Routledge, 2002.

BARTON, Jonathan R. A Political Geography of Latin America. London: Routledge, 2003. 
BOFF, Filippo; SANTANIELLO, Filippo. The Geopolitics of South America: Venezuela and Brazil. Master's Dissertation, Scuola E. Mattei, University of São Paulo, 2006.

BRICS. eThekwini Declaration, Fifth BRICS Summit: Partnership for Development, Integration and Industrialization. Official website of the $5^{\text {th }}$ BRICS Summit. 2013a. Available at: <http://www.brics5.co.za>. Accessed on: September 17 th, 2013.

Fifth BRICS Summit: Partnership for Development, Integration and Industrialization. Official website of the $5^{\text {th }}$ BRICS Summit. 2013b. Available at: <http://www.brics5.co.za>. Accessed on: August 29th, 2013.

BUZAN, Barry; WAEVER, Ole. Regions and Powers: The Structure of International Security. Cambridge: Cambridge University Press, 2003.

CHENG, Hui Fang; GUTIERREZ, Maragarida; MAHAJAN, Arvind; SHACHMUROVE, Yochanan; SHAHROKHI, Manuchehr. A Future Global Economy to Be Built by the BRICS. Global Finance Journal, n. 18, p. 143-156, 2005.

CHILD, John. Geopolitical Thinking in Latin America. Latin American Research Review, v. 14, n. 2, p. 89-111, 1979.

CIA - Central Intelligence Agency. The World Factbook. 2013. Available at: $<$ https://www.cia.gov/library/publications/the-world-factbook>. Accessed on: September 9th, 2013.

CONNELL, R. Interview. Southern Perspectives, 2009. Available at: $<$ http://www.southernperspectives.net/region/australia/interview-with-raewyn-connell>. Accessed on: September 11th, 2013.

DODDS, Klaus. Geopolitics, Cartography and the State in South America. Political Geography, v. 12, n. 4, p. 361-381, 1993.

ELDEN, S. Space I. In: KITCHIN, R.; THRIFT, N. (Ed.). International Encyclopaedia of Human Geography. Amsterdam: Elsevier, 2009.

FERCHEN, Matt. Whose China Model Is It Anyway: The Contentious Search for Consensus. Review of International Political Economy, v. 20, n. 2, 2012.

FERREIRA, Luis. Brazil's Foreign Policy Ambitions and Global Geopolitics. Eurasia Review, 2013. Available at: <http://www.eurasiarevi- 
BRICS: An Explanation in Critical Geography

ew.com/16092013-brazils-foreign-policy-ambitions-global-geopolitics-analysis>. Accessed on: September 18th, 2013.

GERACE, Michael P. Between Mackinder and Spykman: Geopolitics, Containment and After. Comparative Strategy, n. 10, p. 347-367, 1991.

HARVEY, D. Social Justice and the City. Baltimore: Johns Hopkins University Press, 1973.

. The Sociological and Geographical Imaginations. International Journal of Political and Cultural Sociology, v. 18, n. 1, p. 211-255, 2005.

JEONG, Kap-Young; KIM, Euysung. The Global Financial Crisis: New Implications and Perspectives for Emerging Economies. Global Economic Review: Perspectives on East Asian Economies and Industries, v. 39, n. 1, p. 1-13, 2010.

KACOWICZ, Arie M. Geopolitics and Territorial Issues: Relevance for South America. Geopolitics, v. 5, n. 1, p. 81-100, 2000.

KITCHIN, R. Space II. In: KITCHIN, R.; THRIFT, N. (Ed.). International Encyclopaedia of Human Geography. Amsterdam: Elsevier, 2009.

LEFEBVRE, Henry. The Production of Space. Oxford: Blackwell, 1991.

LEMKE, Douglas. Regions of War and Peace. Cambridge: Cambridge University Press, 2003.

MACKINDER, Halford J. The Round World and the Winning of Peace. Foreign Affairs, v. 21, n. 4, p. 595-605, 1943.

MERRIFIELD, A. Henri Lefbvre: A Socialist in Space. In: CRANG, M.; THRIFT, N. (Ed.). Thinking Space. London: Routledge, 2003.

MEYER, P. J. Brazil-US Relations. CRS Report for Congress7-5700, US Congressional Research Service, 2011.

NEUMANN, Roderick P. Political Ecology II: Theorizing Region. Progress in Human Geography, v. 34, n. 3, p. 368-374, 2010.

SCHWAM-BAIRD, David M. Ideas and Armaments: Military Ideologies in the Making of Brazil's Arms Industries. Lanham: University Press of America, 1997. 
SHEKHOVTSOV, Anton. Aleksandr Dugin's Neo-Eurasianism: The New Right à la Russe. Religion Compass, v. 3, n. 4, p. 697-716, 2009.

SHORT, J. R. Global Dimensions: Space, Place and the Contemporary World. London: Reaktion, 2001.

SIDAWAY, James D. Geographies of Development: New Maps, New Visions? The Professional Geographer, v. 64, n. 1, p. 49-62, 2012.

SINHA, Kounteya. India Is Top Arms Buyer, China Unseats UK as 5th Largest Seller. The Times of India, New Delhi, March 19th, 2013.

SPYKMAN, Nicholas J. America's Strategy in World Politics: The United States and the Balance of Power. New York, Harcourt, Brace and Company, 1942.

TOMANEY, J. Region. In: KITCHIN, R.; THRIFT, N. (Ed.). International Encyclopaedia of Human Geography. Amsterdam: Elsevier, 2009.

VAYRYNEN, Raimo. Regionalism: Old and New. International Studies Review, v. 5, n. 1, p. 25-51, 2003.

VENU, M. K. BRICS Moves Towards Creating Fund to Steady Market. The Hindu, New Delhi, September 6th, 2013.

WOUTERS, Jan; RUYS, Tom. Security Council Reforms: A New Veto for a New Century. Egmont Paper 9, Royal Institute for International Relations, Brussels, 2005.

\section{Abstract}

\section{BRICS: An Explanation in Critical Geography}

BRICS, an abbreviation for Brazil, Russia, India, China and South Africa, a group of five influential and emerging economies successfully completed its fifth annual summit in Durban during March 26-27, 2013. A significantly unique feature of the group is its geographical spread as evident from the location of these five constituent states which are situated in four continents. The paper seeks to explain the phenomenon of the 
BRICS: An Explanation in Critical Geography

disparate group BRICS through literature in Critical Geography as it is understood that the recent phase of globalization has created spatial patterns which were hitherto not experienced and therefore not clearly recognized in the literature on International Relations and traditional geography. Such spatially variegated groupings like the BRICS could be analyzed and interpreted in Critical Geography and Critical Geopolitics literature through three important concepts: a) Space b) Geographical and Geopolitical Imaginations and c) Region. The paper seeks to explain BRICS through these conceptual tools.

Keywords: BRICS - Critical Geography - Geopolitical Imaginations 